\title{
Analysis of the Low-Income Housing in Isfahan
}

\section{Metropolis}

\author{
Sayyed Jamaleddin Samsam Shariat ${ }^{1}$, Asghar Zarrabi ${ }^{2} \&$ Masoud Taghvaei ${ }^{3}$ \\ ${ }^{1} \mathrm{PhD}$. Candidate of Geography and Urban Planning, Department of Geography and Urban Planning, Faculty of \\ Geographical Sciences and Planning, University of Isfahan, Iran \\ 2 Professor of Geography and Urban Planning, Department of Geography and Urban Planning, Faculty of \\ Geographical Sciences and Planning, University of Isfahan (Corresponding author), Iran \\ ${ }^{3}$ Professor of Geography and Urban Planning, Department of Geography and Urban Planning, Faculty of \\ Geographical Sciences and Planning, University of Isfahan, Iran \\ Correspondence: Sayyed Jamaleddin Samsam Shariat, Department of Geography and Urban Planning, Faculty of \\ Geographical Sciences and Planning, University of Isfahan, Iran. E-mail: alireza_karbalaei_2007@yahoo.com
}

Received: October 26, 2016

Accepted: November 8, 2016

Online Published: January 26, 2017

doi:10.5539/mas.v11n3p120

URL: http://dx.doi.org/10.5539/mas.v11n3p120

\begin{abstract}
Despite the importance of housing in human life, the provision of adequate and affordable housing for all people is one of the current problems of the human society because almost half of the world's population lives in poverty and about 600 to 800 million people reside in substandard housing conditions. The present study, therefore, has been conducted in order to identify the needy groups and, too, housing the low-income groups in Isfahan City. The study is a fundamental-applied research adopting a descriptive-analytical methodology. Variables of the research are the income deciles, housing quantity developments, land and housing prices, the system of housing finance, housing status in the expenditure basket of the low-income households, the Gini coefficient of housing costs, the effective demand for housing in the income deciles considering the area of infrastructure and the access to housing index. The findings reveal that the year 2008 had the highest increase in the housing prices with an increase as $20.4 \%$ and the lowest one refers to the year 2010 with an increase as $8.6 \%$. The Gini coefficient of housing cost for urban households shows a downtrend until 2005 and from 2006 onward, the gap has started to increase. Regarding access to the housing index, the results show that in 2003 the low income decile could afford one square meter of housing by saving the total household income for 75 days; whereas in 2011, this degree raised to 206 days. What is noteworthy here is the deep gap between the high-income and low-income deciles in the saving days for one square meter, which differs 10.5 times between the first decile and the tenth decile.
\end{abstract}

The present article has been extracted from a PhD dissertation.

Keywords: housing planning, low incomes, housing funds, the metropolis of Isfahan

\section{Introduction}

Buying a house is often the biggest problem for a family in its lifetime. Furthermore, economic, social, and physical properties of the neighborhoods have short term and long term effects on the residents' physical and psychological status (Ellen et al., 1997). Accordingly, inappropriate housing would bring about many health risks, in a way that it would inflict adults, as well as children, with a variety of mental and physical disorders (Bratt, 2000; Kreiger \& Higgens, 2002). Instable housing conditions, moreover, lead to stress and thus have manifold negative effects on people's education and professions (Rothstein, 2000). Despite the importance of housing in the human life, the provision of adequate and affordable housing for all people is one of the current problems of the human society because almost half of the world's population lives in poverty and about 600 million to 800 million people reside in substandard housing conditions (Datta \& Jones, 2001). Despite poor housing conditions in developing countries, there are no organizations and institutions for supplying services and organizing institutional developments so as to strengthen different classes of the society (Anzorena, 1993; Arrossi et al., 1994). For example, $15 \%$ of people in Lagos, $51 \%$ in Delhi, $75 \%$ in Nairobi, and $85 \%$ in Lahore live in substandard housing. It has been estimated that thousands of low-income residents do not use healthy water transported from 
pipes and thus are pushed to use infected or substandard water (Hardoy, Mitlin \& Satterthwaite, 2001). For instance, $33 \%$ of people in Bangkok and 5 million in Kolkata do not have access to healthy water and $95 \%$ of people in Khartoum live without sewage system. According to the report of the World Health Organization, the probability of death in children who live in substandard settlements is 40 to $50 \%$ higher than the children in European and North-American children (Benton-short and Short, 2008). That is because where they live is lacking in security and essential infrastructures and facilities like water, electricity and sewage; in addition, they are also vulnerable to numerous risks (Brunn, Williams \& Ziegler, 2003). In 2005, about 30 environmental disasters led to a death toll of almost 90 thousand people, a majority of whom were from poor countries and low-income people (Chafe, 2006).

Planning in the housing sector in Iran is lacking an efficient statistical system. Despite these paradoxes, gaps and inconsistencies in the data and statistics from the housing sector, reaching to a comprehensive and clear plan to address the problems of this sector is almost beyond any possibility. The lack of cohesion among organizations responsible for collecting and arranging housing index information (Statistical Center of Iran, the Central Bank, Ministry of Housing and Urban Development, municipalities, etc.) should be considered as a serious problem. Aiming at evaluating the status of income groups and housing indicators — such as the average level of infrastructures, the average level of income, etc. - in existing deciles, the present study, therefore, has estimated housing demands and evaluated the financial power of low-income groups in aIsfahan so as to apply the given results in accurate planning of housing for the low-income groups in Isfahan.

\subsection{Theoretical Framework}

Housing is the smallest component of accommodations and is the concrete representation of development. According to Williams (2000), cities embracing social justice are those cities that have the greater share of high-density housing and provide services and facilities. Rappaport (1969) maintains that the factors of culture and human understanding of the universe, together with life, have played a crucial role in housing and its spatial divisions. According to Le Corbusier's viewpoint, a house must response to both physical and spiritual needs of people (Yagi, 1987). Housing is the basic environment of a family, and it is a safe place to wrest away from the routines of work and school, and is a private space. According to Fletcher, houses are paradoxical grounds of both tenderness and violence. Gaston Bachelard in the book, The Poetics of Space, has called home as an "atmosphere of happiness", wherein rest, self-discovery, relaxation and maternity become significant. According to Short (2006), housing is the nodal point of all dualities and paradoxes. Housing and housing planning have been analyzed from different perspectives.

The growth pole theory puts the acute housing problems as something transitional and as parts of development programs (Shefa'at, 2006). On the contrary, the theory of dependency counter-urbanization has recognized inequality and the one-sided product distribution from margin to the center as the main reason for housing deterioration (Athari, 2003).

From an economic viewpoint of the market, housing issues should be left to the market mechanism (Dojkam, 1994), and housing needs of the market system should be provided by the private sector (Seifaldini, 1994). The government should also avoid spending funds for low-income housing (Chadwick, 1987). The urban management approach, which, from the point of view of political economy, is a very important orientation, believes that wider social and economic contexts play a role in the formation of urban residential patterns.

One of the most important parts of urban planning is the planning of housing development; economic factors such as cost of living, employment bases and instability of income play very important roles in housing planning. Beside the economic factor, the architectural style is the most determining factor in housing planning. Regional indigenous languages, stylistic trends, weather, geography, local customs, and other factors influence the development of housing planning and housing design. The five characteristics of housing are: the type of building, style, density, the size of the project, and location (Sendich, 2006). Housing planning should be designed in such a way that in addition to adequate housing, basic ecological variables also to be included in (Inanloo, 2001). Governments often do housing planning at three categories of national, regional and municipal levels so as to be able to employ it as a technique to solve the housing problems of its citizens (Ziari \& Dehghan, 2003).

The fundamental goal of housing planning in national level is to balance the housing supply and demand regarding its position in macroeconomics (Sadeghi, 2003). In regional planning of housing, supply and demand are evaluated in regional level and the aim is to balance them. The difference between housing planning in regional level and national level is that in regional level the relation between housing and macroeconomics is not considered, but it emphasizes on the economic potentials inside the regions (Zebardast, 2003). Local housing planning is conducted in three scales of town, city and urban areas. 
Housing planning can be approached in two different ways. The first approach is the distribution of the goals and credits of national and regional plans to smaller geographic scales of region, city or town. The second approach is to investigate the housing status at local levels and to estimate the needed land for future housing development and suitable differentiation of the lands (Tofigh, 2003). The other approach is concerned with the low-income housing and presents three programs: 1 . Those programs providing subsidies for rental housing, either as individual or in complexes; 2. those providing tax credits that result in the production of low-rent housing units; 3 . supportive programs for affordable housing of the lower classes (Mills et al, 2006). Such a policy is along with tools such as tax-deductibility, long-term loans, insurance, and so forth.

The UN addresses the housing of those in need through the Commission on Human Settlements in the form of Habitat Program. In 1986, the UN codified the Global Shelter Strategy for the Homeless until the year 2000 with an empowerment approach. In 1992, there was addressed in Habitat 2 the security of the right for housing, particularly for the low incomes. In 2001, in the special session of the UN General Assembly in New York, the need to address the issue of urban poverty and homelessness received serious considerations.

\section{Methodology}

This study is a fundamental-applied piece of research adopting a descriptive-analytical method. The geographic area of the research is the political and administrative area of Isfahan City in 2014. Variables of the research are the income deciles, housing quantity developments, land and housing prices, the system of housing finance, housing status in the expenditure basket of the low-income households, the Gini coefficient of housing costs, the effective demand for housing in the income deciles considering the area of infrastructure and the access to housing index. The Statistical Centre of Iran provided the statistics and Isfahan provided the cost/income scheme. Methods used include statistical techniques of the population deciles and affordability of the groups, there has been used the function of the indirect method.

\section{Results}

\subsection{Changes in the Quality of Housing in Isfahan}

According to the statistics, the population and urban growth had a great growth in decade from 1996 to 2006 . The average of population growth in the years from 1996 to 2006 was $1.37 \%$, the growth of the households was $52.3 \%$ and the growth of housing was $7.3 \%$ (Table 1 ).

According to the 2011 census, the population was about 1,908,968 individuals residing in 602,198 households, hence the size of each household is 3.17 individuals. However, the number of housing units constructed in the same year for 602,198 households in Isfahan was not standard and there was a housing shortage to the level as 0.193. But with the growth in the number of housing units in 2011, it can be stated that the 215000-unit policy of the Mehr Housing Project has had a large impact on the number of housing units in Isfahan (see Table 1).

Table 1. Changes in the quantity of housing in Isfahan compared to its population changes (period 1996-2011)

\begin{tabular}{|c|c|c|c|c|c|c|c|c|c|}
\hline Period & Population & $\begin{array}{l}\text { number of } \\
\text { households }\end{array}$ & $\begin{array}{l}\text { size of the } \\
\text { household }\end{array}$ & $\begin{array}{l}\text { Number of } \\
\text { typical } \\
\text { residential } \\
\text { units }\end{array}$ & $\begin{array}{l}\text { Proportion of } \\
\text { households to } \\
\text { residential units }\end{array}$ & $\begin{array}{l}\text { Population } \\
\text { growth rate }\end{array}$ & $\begin{array}{l}\text { Urbanizat } \\
\text { on rate in } \\
\text { percent }\end{array}$ & $\begin{array}{l}\text { i Shortage of } \\
\text { housing } \\
\text { regarding the } \\
\text { households }\end{array}$ & $\begin{array}{l}\text { Percent of } \\
\text { housing shortage } \\
\text { to the existing } \\
\text { ones }\end{array}$ \\
\hline 1996 & 1310659 & 326581 & 4.03 & 325225 & 1.239 & 1.51 & 74 & 1356 & 0.416 \\
\hline 2006 & 1642996 & 466760 & 3.52 & 458852 & 7.541 & 1.37 & 83 & 7908 & 1.723 \\
\hline 2011 & 1908968 & 602198 & 3.17 & 601035 & 5.264 & 1.3 & 85 & 1163 & 0.193 \\
\hline
\end{tabular}

Source: the researcher's calculations, 2014

\subsection{Evaluation of the Price Changes of Land and Housing in Isfahan}

The value of properties (land, housing, and rent prices) is one of the main factors in determining the quality and quantity of people's housing; while housing and land become the playground of one's capital (as in current Iranian conditions), the tendency to have private housing increases and this issue leads to an increase in housing demands. Considering the instable status and the risks following certain other investment areas (such as manufacturing and agriculture, etc.), the tendency towards investing in housing sector has always been a safer investment and this has led to increase in the prices and widen the gap between effective demands and the potential demands. 
During the evaluation, we encounter huge fluctuation in the value of housing lands, both dilapidated and new, and an increase in the housing rent prices, as has been presented in detail in Table 2.

Table 2. Changes in prices of land, housing, and rents, 2003-2013

\begin{tabular}{|c|c|c|c|c|c|c|}
\hline \multirow[t]{2}{*}{ Year } & \multicolumn{2}{|c|}{$\begin{array}{l}\text { A square meter of dilapidated residential } \\
\text { building }\end{array}$} & \multicolumn{2}{|c|}{ A square meter of residential units } & \multicolumn{2}{|c|}{ Rent prices for one square meter } \\
\hline & $\begin{array}{l}\text { Price (a thousand } \\
\text { rials) }\end{array}$ & $\begin{array}{l}\text { Annual growth } \\
\text { rate }\end{array}$ & $\begin{array}{l}\text { Price (a thousand } \\
\text { rials) }\end{array}$ & $\begin{array}{l}\text { Annual growth } \\
\text { rate }\end{array}$ & $\begin{array}{l}\text { Price (a thousand } \\
\text { rials) }\end{array}$ & $\begin{array}{l}\text { Annual growth } \\
\text { rate }\end{array}$ \\
\hline 2003 & 2632 & - & 3007 & - & 13034 & - \\
\hline 2004 & 3562 & 35.3 & 3373 & 10.8 & 13177 & 1.08 \\
\hline 2005 & 4035 & 11.7 & 4251 & 20.6 & 14582 & 9.6 \\
\hline 2006 & 3839 & -5.1 & 4702 & 9.5 & 16313 & 10.6 \\
\hline 2007 & 5706 & 32.7 & 8181 & 42.5 & 20975 & 22.2 \\
\hline 2008 & 7278 & 21.5 & 8485 & 3.5 & 24600 & 17.5 \\
\hline 2009 & 4929 & -47.6 & 8211 & -3.3 & 25195 & 18.2 \\
\hline 2010 & 4612 & -6.8 & 8676 & 5.3 & 28333 & 11.07 \\
\hline 2011 & 4978 & 7.3 & 9549 & 9.1 & 30075 & 5.7 \\
\hline 2012 & 6332 & 10.2 & 12385 & 22.8 & 35809 & 16.01 \\
\hline 2013 & 8571 & 26.1 & 16624 & 25.4 & 45261 & 20.8 \\
\hline
\end{tabular}

Source: Statistical Center of Iran, Statistical Yearbook of Isfahan Province, 2003-2004

Considering the price per square meter of housing units in Isfahan, we see that the market of such land had a great fluctuation between the years of 2004 and 2006 and immediately fell in 2007 . Bu the most fluctuation was in 2009 when the price of dilapidated units had a decrease as $-47.6 \%$ and this decrease continued in the following year and it then found an increase process. The outset of the Mehr Housing Project, the economic downturn in the investing countries (foreign participation sharply declined), and political issues can nevertheless be assumed as the main reasons of the price drop in the years between 2009 and 2010 .

However, during the period, the price of housing units per square meter was with a greater stability, in a way that except the year 2009, when a 3.3\% negative growth was experienced, there experienced no more descending in prices. One of the characteristics of the housing market during the research was the increase in the prices. Evaluation of the inflation indexes, the prices of manufacturing factors, and housing prices show that the housing market in Isfahan has not been mainly exempted from self-seeking interventions and the bulk of the increase in housing prices were resulted from rising prices of production factors and the overall inflation.

An important issue here is that the difference between the rental prices and housing prices was its continuous increase during the years under study.

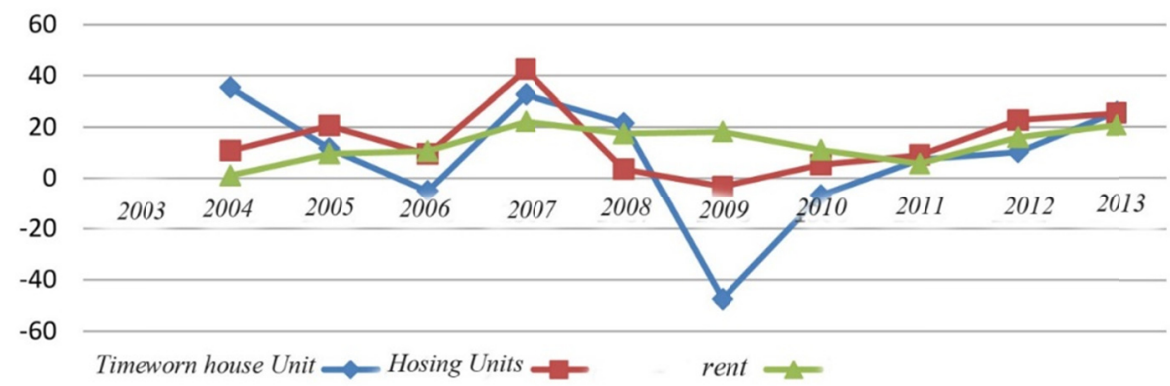

Figure 1. Changes in rental housing prices, land and rent during the period 2003-2013

Source: Statistical Center of Iran and author's calculations, 2014

\subsection{Study of the Changes in the Production of Housing in Isfahan}

Increase in land prices, as one of the most important components of the production of housing, has brought about the grounds for a decrease in the production of housing on the one hand, and an increase in building density factor on the other hand. The cost of housing in Isfahan per square meter is another indicator that can be 
objectively applied in the analysis of access to adequate housing. Of course, the cost of housing will increase over time, but the process of the increase is of importance. At the beginning of the period under study the cost of making one meter square of housing in Isfahan was 430,000 IRR, while this amount was 3,102,000 IRR at the end of the period. Although changes in housing investment, in short-term, are affected by the changes in the factors affecting the demand, such as housing prices and the granting of loans, the long-term factors such as land prices, construction costs and inflation also affect these changes. The cost of housing production during the period has had always an upward trend, but the acceleration of this growth has been different. Much of the increase in the construction cost was due to the rising prices of the land, materials, and labor. Some have been affected by the decline in productivity.

Table 3. Changes in the cost of housing construction per square meter, 2001-2012 (one thousand IRR)

\begin{tabular}{lccccccc}
\hline $\begin{array}{l}\text { Year } \\
\text { Index }\end{array}$ & $\mathbf{2 0 0 1}$ & $\mathbf{2 0 0 6}$ & $\mathbf{2 0 0 8}$ & $\mathbf{2 0 0 9}$ & $\mathbf{2 0 1 0}$ & $\mathbf{2 0 1 1}$ & $\mathbf{2 0 1 2}$ \\
\hline The cost of one square meter construction & 430 & 1308 & 1542 & 2030 & 2441 & 2582 & 3102 \\
Percent of growth comparing to the previous year & - & 204 & 17.8 & 31.6 & 20.2 & 5.7 & 20.1 \\
\hline
\end{tabular}

Source: Statistical Center of Iran, the Central Bank of the Islamic Republic of Iran, 2001-2012 and author's calculations

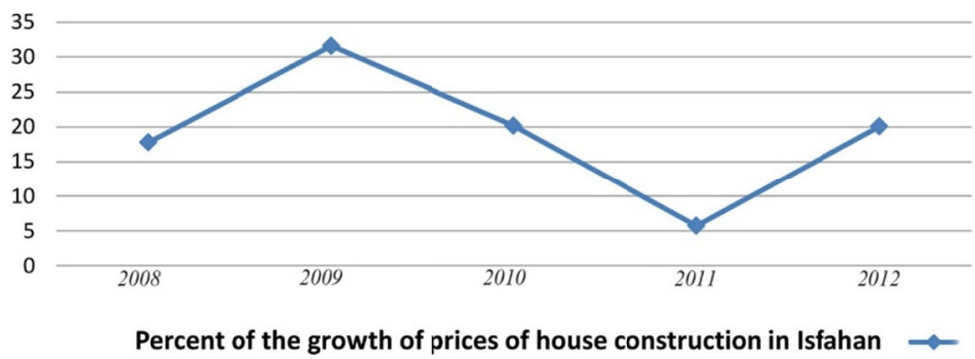

Figure 2. Changes in the cost of housing construction per square meter 2001-2012 (percent)

\subsection{Evaluation of Housing Finance System in Isfahan}

\subsubsection{Household Savings}

In the area of private housing, the greatest and most reliable source in providing housing is a household's savings. Household's savings are part of households' disposable income that are not used by the household and are therefore saved. In this study, to achieve cost savings level, the difference between household income and household expenditure is computed (Table 4).

Table 4. Mean income, cost, and savings of an urban household over the years 2006-2012 (IRR

\begin{tabular}{llll}
\hline Year & Price & Income & Savings \\
\hline $\mathbf{2 0 0 6}$ & 69059825 & 57289929 & -11769896 \\
$\mathbf{2 0 0 9}$ & 88508931 & 74529939 & -13978992 \\
$\mathbf{2 0 0 9}$ & 101319582 & 87730581 & -13589001 \\
$\mathbf{2 0 1 0}$ & 114495202 & 93390015 & -21105187 \\
$\mathbf{2 0 1 1}$ & 137279114 & 109217181 & -28061933 \\
$\mathbf{2 0 1 2}$ & 157761405 & 145924872 & -11836533 \\
\hline
\end{tabular}

Source: Statistical Yearbook of Isfahan Province and author's calculations (2014)

During the study period, household savings have been negative for most of the period. Accordingly, assuming the consumption pattern of households to be constant, households' savings cannot be a source of funding for housing. But it is possible that by changing the consumption patterns and lifestyles, and by increasing the savings, it can be insisted on as a source of housing.

\subsubsection{Bank Credits}

Credit and banking facilities are financing or guaranteeing the obligations of the applicants based on the 
interest-free banking law, where the methods of banking facilities include: loan, civic management, legal management, direct investment, partnership, forwards, sales installment, hire-purchase, contract of farm letting .

Table 5. Amount of the grants by the banks of Isfahan Province to private sector based upon major economic sectors, 2001-2012

\begin{tabular}{llllllll}
\hline Index & $\mathbf{2 0 0 1}$ & $\mathbf{2 0 0 6}$ & $\mathbf{2 0 0 8}$ & $\mathbf{2 0 0 9}$ & $\mathbf{2 0 1 0}$ & $\mathbf{2 0 1 1}$ & $\mathbf{2 0 1 2}$ \\
\hline $\begin{array}{l}\text { The number of facilities and bank } \\
\text { credit }\end{array}$ & 170128 & 384418 & 262110 & 160060 & 308439 & 567426 & 328695 \\
Percentage of total housing per year & 28.67 & 35.21 & 16.5 & 9.49 & 12.18 & 21.45 & 12 \\
\hline
\end{tabular}

Source: Statistical Yearbook of Isfahan Province and author's calculations (2014)

In total, the annual average of 20 percent of bank credits has been allocated to the housing sector which is a substantial amount. Therefore, considering the financial sources and potentials and absorption rate of bank deposits by the banks of the province, $20 \%$ of them can be considered as sources of investment in the housing sector.

\subsubsection{Bank Development Credits}

Government's development credits are the budget allotted annually and based on annual budget rules for implementing development plans and for expanding current expenditure on the government's economic and social plans, nationally and provincially. This budget is divided into the three general, economic and social categories.

Table 6. Government credits as divided by budget seasons (2006-2012)

\begin{tabular}{llllllll}
\hline Year & Sum & \multicolumn{2}{l}{ General affairs } & \multicolumn{2}{l}{ Social affairs } & \multicolumn{2}{l}{ Economic affairs } \\
\cline { 3 - 8 } & & Credit & percentage & Credit & percentage & Credit & percentage \\
$\mathbf{2 0 0 6}$ & 8928397 & 6947286 & 77.8 & 556603 & 6.2 & 1424508 & 15.9 \\
$\mathbf{2 0 0 8}$ & 5461355 & 1175093 & 21.5 & 1250856 & 22.9 & 3035406 & 55.5 \\
$\mathbf{2 0 0 9}$ & 3177898 & 1866020 & 58.7 & 544190 & 17.1 & 767688 & 24.1 \\
$\mathbf{2 0 1 0}$ & 3996923 & 2074964 & 51.9 & 700944 & 17.5 & 1221015 & 30.5 \\
$\mathbf{2 0 1 1}$ & 4031126 & 2338934 & 58.01 & 605371 & 15.01 & 1086821 & 26.9 \\
$\mathbf{2 0 1 2}$ & 2888659 & 2304195 & 79.7 & 161633 & 5.5 & 422831 & 14.6 \\
\hline
\end{tabular}

Source: Statistical Yearbook of Isfahan Province and the author's calculations (2014)

Table 7. Share of credits of the housing sector in social affairs program 2006-2012 (million rials)

\begin{tabular}{lllllll}
\hline Year & $\begin{array}{l}\text { Sum of } \\
\text { credits }\end{array}$ & \multicolumn{2}{l}{$\begin{array}{l}\text { Share of credits of the } \\
\text { economic sector in the total } \\
\text { credits }\end{array}$} & $\begin{array}{l}\text { Share of credits of the housing } \\
\text { sector from the economic } \\
\text { credits }\end{array}$ & $\begin{array}{l}\text { Share of credits of } \\
\text { the housing sector in } \\
\text { the total credits }\end{array}$ \\
\cline { 3 - 7 } & & Credit & Percentage & Credit & Percentage & Percentage \\
$\mathbf{2 0 0 6}$ & 8928397 & 1424508 & 15.9 & 513921 & $36 / 07$ & 5.7 \\
$\mathbf{2 0 0 8}$ & 5461355 & 3035406 & 55.5 & 675548 & 22.2 & 12.3 \\
$\mathbf{2 0 0 9}$ & 3177898 & 767688 & 24.1 & 207621 & 27.04 & 6.5 \\
$\mathbf{2 0 1 0}$ & 3996923 & 1221015 & 30.5 & 419433 & 10.4 & 10.4 \\
$\mathbf{2 0 1 1}$ & 4031126 & 1086821 & 26.9 & 419154 & 38.5 & 10.3 \\
$\mathbf{2 0 1 2}$ & 2888659 & 422831 & 14.6 & 126148 & 29.8 & 3.4 \\
\hline
\end{tabular}

Source: Statistical Yearbook of Isfahan Province and the author's calculations (2014)

Considering the results, it can be argued that the credit of the sector has varied over years, and the these changes ranges from 5 to 12 percent of the entire budget, which is an important figure in its own right.

Of course, this might be due to the role of government and private sector in housing investment. Although in the recent years the government's role has become more serious with the emergence of plans such as Mehr Housing, retroffiting plan, and renovation of distressed areas. (Of course, one must notice that as of 2006 the economic sector has always received the highest credits. And, in the economic sector, the housing, and urban and rural 
sectors received the greatest amounts of credits).

3.4.4 Determining the Position of Housing in the Expenditure Basket of Low-Income Households of Isfahan City

To investigate housing costs in each of the income groups, first the study households were ordered in descending order during the years 2005-2011based on the amount of income. Afterwards, households were divided into equal groups (indicating Deciles). In the next step, based on the data regarding housing costs and the entire food and non-food expenditure of each household, the amount of housing costs and the entire food and non-food expenditure of each of the income Deciles was calculated for different years. Finally, the mean income and housing costs and the total food and non-food costs of households in each Decile were investigated. In order to present authentic and real analyses, all variables were calculated considering the ratio of price index in Isfahan to the fixed price of the year 2005.

Table 8. Mean housing cost of low-income household of Isfahan City (2005-2011)

\begin{tabular}{lll}
\hline Year & Mean cost & Proportion of growth compared to previous year \\
\hline $\mathbf{2 0 0 5}$ & 14124382 & - \\
$\mathbf{2 0 0 6}$ & 17433765 & 18.9 \\
$\mathbf{2 0 0 7}$ & 21248483 & 17.9 \\
$\mathbf{2 0 0 8}$ & 26704381 & 20.4 \\
$\mathbf{2 0 0 9}$ & 26390670 & -1.18 \\
$\mathbf{2 0 1 0}$ & 28886146 & 8.6 \\
$\mathbf{2 0 1 1}$ & 33238345 & 13.09 \\
\hline
\end{tabular}

Source: Statistical Center of Iran, Plan for household cost and income of Isfahan city (2011)

As displayed in Table 8, housing costs for Isfahan city have an increasing trend (except for the year 2009). The highest increase in housing costs took place in 2008 (\%20.4) and the lowest increase occurred in 2010 (\%8.6).

In this regard, it should be noted that the government's policies to establish stability and regulate market prices and prevent unduly increase have been very effective, such that the rate of price increase in relation to the previous year has been usually in the same price range. However, to present precise results of estimation of housing costs of low-income groups in Isfahan city, the results were analyzed in income Deciles (Table 9).

Table 9. Variation in the mean housing cost of urban households of Isfahan city, 2007-2011

\begin{tabular}{lllllllllll}
\hline Year & $\begin{array}{l}\text { Decile } \\
\mathbf{1}\end{array}$ & $\begin{array}{l}\text { Decile } \\
\mathbf{2}\end{array}$ & $\begin{array}{l}\text { Decil } \\
\text { e 3 }\end{array}$ & $\begin{array}{l}\text { Decil } \\
\text { e } 4\end{array}$ & $\begin{array}{l}\text { Decile } \\
\mathbf{5}\end{array}$ & $\begin{array}{l}\text { Decile } \\
\mathbf{6}\end{array}$ & $\begin{array}{l}\text { Decil } \\
\text { e 7 }\end{array}$ & $\begin{array}{l}\text { Decile } \\
\mathbf{8}\end{array}$ & $\begin{array}{l}\text { Decile } \\
\mathbf{9}\end{array}$ & Decile 10 \\
\hline $\mathbf{2 0 0 7 - 2 0 1 1}$ & 25.14 & 28.2 & 28.9 & 25.7 & 32.5 & 33.68 & 33.3 & 35.58 & 34.33 & 36.1 \\
\hline
\end{tabular}

Source: Statistical Center of Iran, Plan for household cost and income of Isfahan city (2011)

As can be seen, enforcement of various economic policies in the housing sector and establishment of a balance between housing supply and demand in Isfahan city during the study period has been such that the average housing costs for high-income households was higher than low-income households. The highest increase belonged to the $10^{\text {th }}$ Decile (\%36.1) and the lowest increase belonged to the $4^{\text {th }}$ Decile $(\% 25.7)$.

In the following sections, to present precise results, the share of housing costs in the total costs of urban households will be analyzed in income Deciles (Table 10).

Table 10. Share of housing costs in the total costs of urban households of Isfahan, 2007-2011.

\begin{tabular}{ccccccccccc}
\hline Year & $\begin{array}{c}\text { Decile } \\
1\end{array}$ & $\begin{array}{c}\text { Decil } \\
\text { e } 2\end{array}$ & $\begin{array}{c}\text { Decile } \\
3\end{array}$ & $\begin{array}{c}\text { Decil } \\
\text { e } 4\end{array}$ & $\begin{array}{c}\text { Decile } \\
5\end{array}$ & $\begin{array}{c}\text { Decile } \\
6\end{array}$ & $\begin{array}{c}\text { Decil } \\
\text { e } 7\end{array}$ & $\begin{array}{c}\text { Decile } \\
8\end{array}$ & $\begin{array}{c}\text { Decile } \\
9\end{array}$ & Decile 10 \\
\hline $\begin{array}{c}2007-201 \\
1\end{array}$ & 47.4 & 46.49 & 44.15 & 42.2 & 40.38 & 38.6 & 35.56 & 34.33 & 33.9 & 31.5 \\
\hline
\end{tabular}

Source: Statistical Center of Iran, Plan for household cost and income of Isfahan city (2011) 
According to the results, in general, the share of housing costs in the high-income households (31.5), the share of housing costs is lower than that in the low-income households (47.4). Put otherwise, Isfahan urban households belonging to the lower Deciles of the society spend a great proportion of their income (food and non-food expenses) on housing costs. In contrast, households of upper Deciles devoted a smaller proportion of their income on housing costs. Hence, in the upper income Deciles, the share of housing costs compared to the total costs of households is lower than that in households of the lower Deciles of Isfahan city.

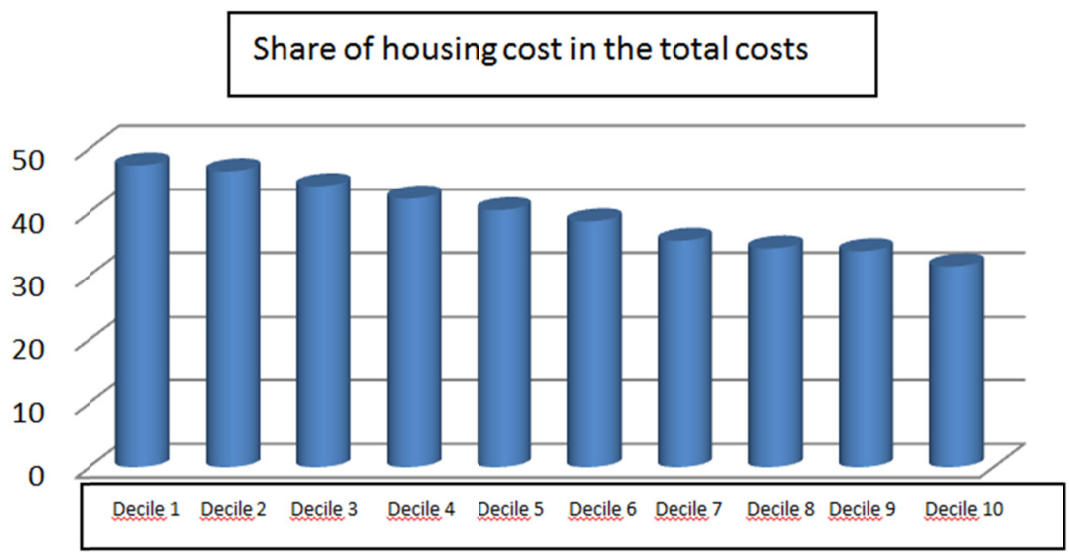

Figure 3. Share of housing costs in the total costs of urban households in Isfahan city within the framework of income Deciles (2007-2011)

\subsubsection{Estimation of Gini Coefficient of Housing Costs of Households of Isfahan City}

This index id usually used to investigate class difference and income distribution among the society's Deciles. Therefore, the closes the value to 1 , the less unequally distributed of the index, and the closer it is to zero, the more equally distributed the index.

Here, the Abunoori equation is used to calculate Gini coefficient.

$$
\log \left[\frac{f(y)}{1-f(y)}\right]=\log \mathrm{a}+1 / \mathrm{g} \log \mathrm{y}+\mathrm{u}
$$

Where ' $y$ ' stands for the upper limit of expenditure groups, $f(y)$ is the relative cumulative frequency of households with expenditure up to ' $y$ ', and ' $u$ ' stands for regression error. Table 11 presents the values of Gini coefficient for the housing costs of households of Isfahan city.

Table 11. Gini coefficient of housing costs of urban households in Isfahan city

\begin{tabular}{llllllllll}
\hline Year & $\mathbf{2 0 0 3}$ & $\mathbf{2 0 0 4}$ & $\mathbf{2 0 0 5}$ & $\mathbf{2 0 0 6}$ & $\mathbf{2 0 0 7}$ & $\mathbf{2 0 0 8}$ & $\mathbf{2 0 0 9}$ & $\mathbf{2 0 1 0}$ & $\mathbf{2 0 1 1}$ \\
\hline $\begin{array}{l}\text { Gini } \\
\text { coefficient }\end{array}$ & 0.323 & 0.306 & 0.294 & 0.309 & 0.317 & 0.343 & 0.370 & 0.400 & 0.405 \\
\hline
\end{tabular}

Source: Author's calculations based on Plan for costs and income of urban households of the Province (2003-2011)

During the study period, the Gini coefficient for housing costs for urban households had a generally descending order, which indicates a decrease in housing costs among urban households. Of course, this decrease per se could not be a source of optimism about the housing costs of lower income groups, because unless such a decrease is accompanied by decreased equality in the income of households, it indicates an increase in the share of housing in the budget of household and hence greater pressure on them. This gap has been widening as of 2006. Lorenz curve, which was obtained in this study by drawing households' cumulative frequency for cumulative percentage of housing costs, was used to further explain the degree of inequality. The more the Lorenz curve distance from 
the equal distribution line, the more inequality.

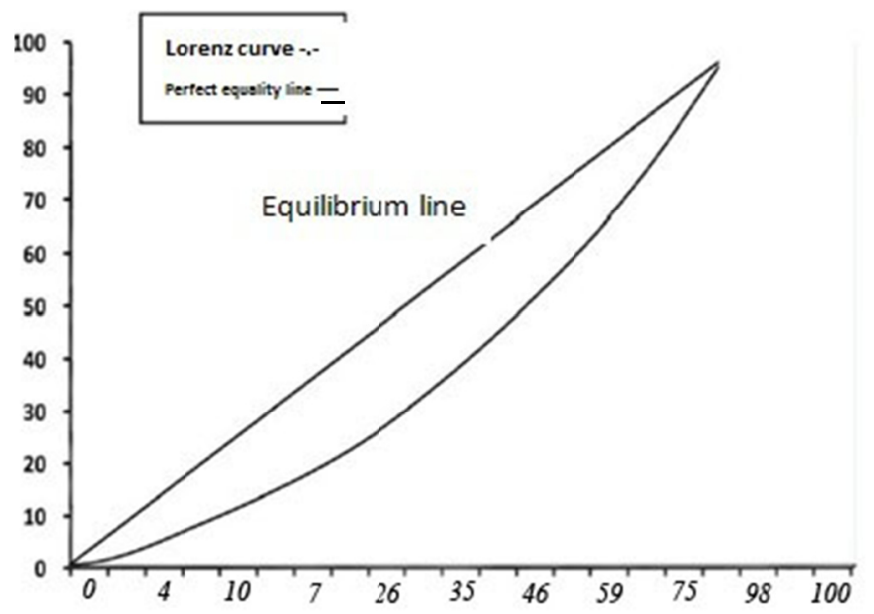

Figure 4. Lorenz curve of the gap between housing costs in income Deciles of urban households in 2011

\subsubsection{Effective Housing Demand in Income Deciles in Terms of Substructure Area in Isfahan City}

The following equation was used to estimate the effective demand of housing units in income Deciles of Isfahan urban households.

$$
\mathrm{W}=\frac{d(c h)}{d(B U)} \times \frac{B U}{P B U}
$$

In the above equation:

Q stands for the amount of effective demand per square meter

$\mathrm{CH}$ represents housing costs of household

$\mathrm{Bu}$ stands for the substructure of the housing unit of household

Table 12 presents in detail the average amount of effective demand in different years in each of the income groups in Isfahan city.

Table 12. Amount of effective demand in different years in each income Decile of Isfahan city (square meter)

\begin{tabular}{llllllllll}
\hline $\begin{array}{l}\text { Year } \\
\text { Decile }\end{array}$ & $\mathbf{2 0 0 3}$ & $\mathbf{2 0 0 4}$ & $\mathbf{2 0 0 5}$ & $\mathbf{2 0 0 6}$ & $\mathbf{2 0 0 7}$ & $\mathbf{2 0 0 8}$ & $\mathbf{2 0 0 9}$ & $\mathbf{2 0 1 0}$ & $\mathbf{2 0 1 1}$ \\
\hline Decile 1 & 4.6 & 7 & 4.5 & 6 & 5 & 4 & 2 & 1.3 & 1.9 \\
Decile 2 & 7.5 & 12 & 8 & 7.8 & 5.5 & 4.5 & 3.7 & 2.4 & 2.5 \\
Decile 3 & 9.4 & 14 & 8.5 & 9 & 5.6 & 5.6 & 5.4 & 3 & 3.8 \\
Decile 4 & 11 & 15.5 & 10 & 10.1 & 6.6 & 7 & 6 & 5 & 4.8 \\
Decile 5 & 13 & 17 & 12.4 & 12 & 7.8 & 8 & 8 & 4.9 & 5.5 \\
Decile 6 & 15 & 21 & 13 & 14 & 10.5 & 9 & 9 & 5.6 & 6.7 \\
Decile 7 & 17 & 26.2 & 14 & 17 & 12 & 10.1 & 11 & 1.7 & 6.4 \\
Decile 8 & 21 & 28 & 9 & 33 & 14.8 & 10.6 & 17 & 8 & 7.4 \\
Decile 9 & 26 & 31 & 23 & 39 & 26.2 & 13 & 19 & 12 & 9 \\
Decile 10 & 49 & 45 & 41 & 45 & 31 & 23 & 25.6 & 24 & 17 \\
\hline
\end{tabular}

Source: Author's measurements based on the Plan for Costs and Income of Urban Households of the province (2003-2011)

Based on the combination of variations of the two factors of income of households of Isfahan city and variation of housing price in urban areas, the outcome of changes in the effective demand among different income Deciles of Isfahan city were presented. As displayed by Table 12, investigation of effective demand among income 
Deciles of the city indicates a wide gap in terms of affording housing between high-income groups and low-income groups of households of Isfahan city.

A more important point is that, based on the results, effective demand for housing units had experienced a decrease in all income deciles at the end years of the study period. Besides, with respect to the ability of effective demand among low-income groups, while Deciles 1 to 4 could afford 4 to 11 square meters of housing in 2003, these numbers reduced to 1.9 to 5 square meters in 2011.

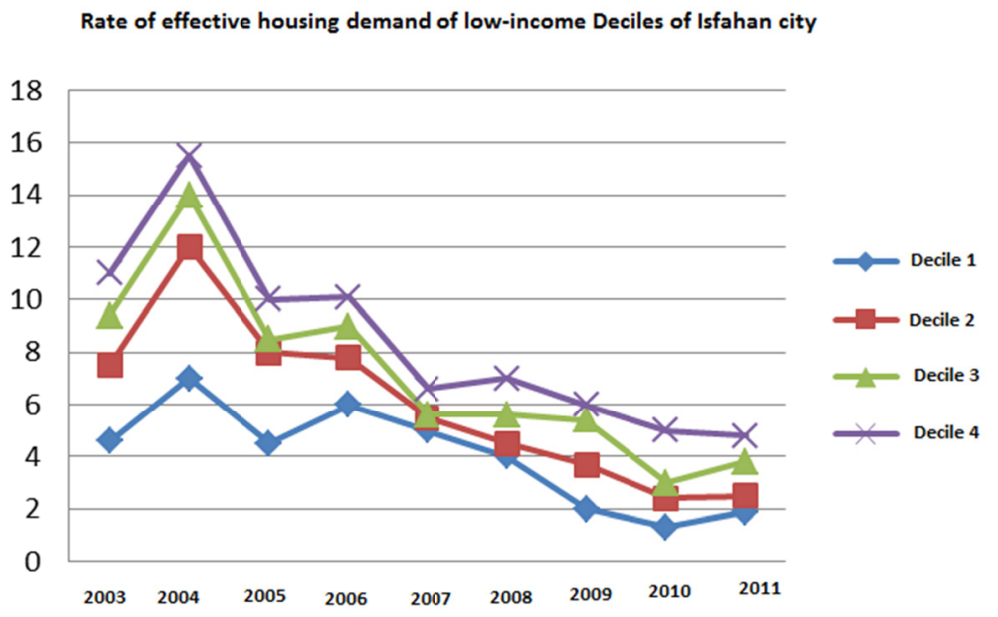

Figure 5. Amount of effective demand in the 4 lowest-income Deciles of Isfahan city

\section{Sum of housing demand of income groups of Isfahan}

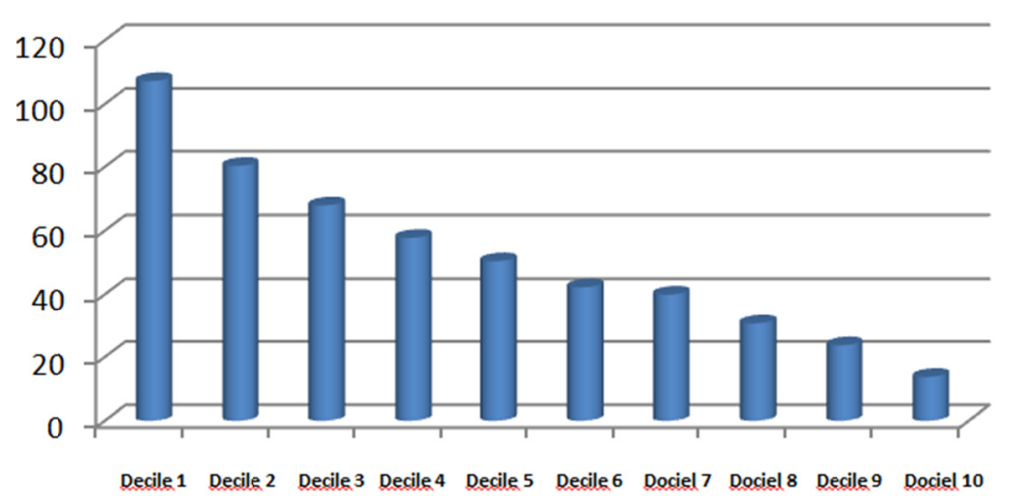

Figure 6. Sum of amount of effective housing demand of income docuiels of Isfahan city (2003-2011)

\subsubsection{Housing Accessibility Index in Different Income Groups of Isfahan}

Housing accessibility index is obtained by dividing each unit of goods by the consumer income in a certain time unit. It shows how many time periods does the consumer have to work to obtain one unit of the intended commodity. Given the fact that the annual consumer's income is considered, assuming that the income is distributed equally among all days of the year, the accessibility index shows how many days' income of a household can buy one square meter of a housing unit.

Accordingly, in upper income dociels, households can own housing units by saving their income in a smaller number of days than the households in the lower Deciles do. Of course, considering the annual increase in the price of each square meter of housing unit, the days whose income must be saved to buy a square meter of housing unit increased in all income Deciles. The results show that in the low-income Decile in 2003, a household can afford a square meter of housing unit by saving the complete income of 75 days, while this number rose up to 206 days in late 2011. 
Table 13. Number of household days whose income is set aside in order to purchase one square meter of housing unit in Isfahan city for income Deciles in different years

\begin{tabular}{lllllllllll}
\hline $\begin{array}{l}\text { Year } \\
\text { Decile }\end{array}$ & $\mathbf{2 0 0 3}$ & $\mathbf{2 0 0 4}$ & $\mathbf{2 0 0 5}$ & $\mathbf{2 0 0 6}$ & $\mathbf{2 0 0 7}$ & $\mathbf{2 0 0 8}$ & $\mathbf{2 0 0 9}$ & $\mathbf{2 0 1 0}$ & $\mathbf{2 0 1 1}$ & $\begin{array}{l}\text { Mean } \\
\text { of } \\
\text { period }\end{array}$ \\
\hline Decile 1 & 75 & 65 & 81 & 94 & 119 & 122 & 135 & 175 & 206 & 107.2 \\
\hline Decile 2 & 68 & 58 & 52 & 77 & 80 & 93 & 103 & 143 & 129 & 80.3 \\
\hline Decile 3 & 63 & 53 & 42 & 56 & 63 & 81 & 96 & 121 & 104 & 67.9 \\
\hline Decile 4 & 58 & 47 & 37 & 43 & 55 & 67 & 82 & 101 & 88 & 57.7 \\
\hline Decile 5 & 50 & 41 & 32 & 40 & 48 & 52 & 63 & 80 & 76 & 50.4 \\
\hline Decile 6 & 49 & 36 & 28 & 34 & 41 & 45 & 50 & 73 & 66 & 42.2 \\
\hline Decile 7 & 43 & 30 & 25 & 30 & 34 & 40 & 43 & 65 & 57 & 39.9 \\
\hline Decile 8 & 34 & 25 & 19 & 27 & 31 & 34 & 33 & 55 & 48 & 30.6 \\
\hline Decile 9 & 29 & 19 & 16 & 22 & 22 & 28 & 28 & 34 & 39 & 23.7 \\
\hline Decile 10 & 10 & 13 & 13 & 14 & 15 & 17 & 17 & 19 & 23 & 13.7 \\
\hline
\end{tabular}

Source: Author's calculations based on Plan for Costs and Income of Urban Households of Isfahan (2003-2011)

Besides, while in 2001 the highest-income Deciles of Isfahan urban society needed to save 10 days' income to afford one square meter, this number rose up to 23 days at the end of the period. The important point is the wide gap between high-income and low-income Deciles in waiting (saving) days for obtaining a square meter, which is 10.5 times between the $1^{\text {st }}$ and $10^{\text {th }}$ Deciles. This trend indicates increased inconvenience and inability in provision of housing.

\section{Household finances}

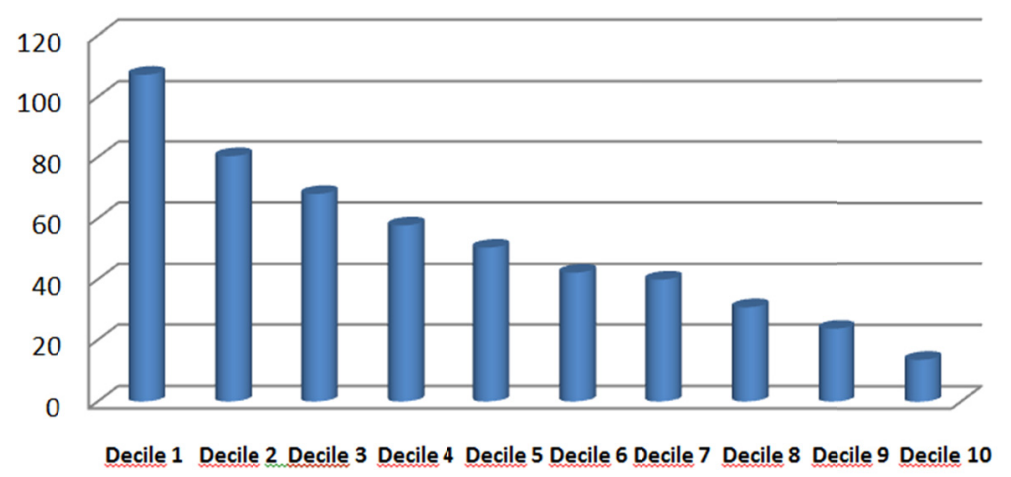

Figure 7. Number of days whose income is set aside to buy one square meter of housing unit

As can be seen, in average, the households of the three upper income Deciles of Isfahan can buy a square meter of land by spending the savings of less than one month of their income, while the households of the three lower Deciles have to spend the savings of 65 days of their income to purchase a square meter of land.

Besides, housing unit accessibility index has also been determined as divided by income groups per year. Table 36.6 shows the trend continuing from 2003 to 2011.

In this regard, it should be noted that by assuming that one-third of the income of households of each income group is saved for obtaining housing, the years required to obtain an average housing unit ( 75 square meters) in Isfahan city for each income group is as follows:

Table 14. Number of years needed for household income (waiting period) to buy a housing unit (75 square meters in average) as divided by income Deciles (2003-2011)

\begin{tabular}{llllllllll}
\hline $\begin{array}{l}\text { Year } \\
\text { Decile }\end{array}$ & $\mathbf{2 0 0 3}$ & $\mathbf{2 0 0 4}$ & $\mathbf{2 0 0 5}$ & $\mathbf{2 0 0 6}$ & $\mathbf{2 0 0 7}$ & $\mathbf{2 0 0 8}$ & $\mathbf{2 0 0 9}$ & $\mathbf{2 0 1 0}$ & $\mathbf{2 0 1 1}$ \\
\hline Decile 1 & 48.4 & 33 & 36 & 58 & 70 & 75 & 84 & 91 & 103 \\
Decile 2 & 30 & 21 & 30 & 38 & 48 & 50 & 71 & 85 & 97 \\
\hline
\end{tabular}




\begin{tabular}{|llllllllll}
\hline Decile 3 & 24 & 18.6 & 26.2 & 29 & 43 & 42.3 & 63.6 & 64 & 87 \\
\hline Decile 4 & 20.2 & 16.5 & 21.8 & 23.4 & 36 & 35.5 & 50.5 & 58.6 & 68.6 \\
\hline Decile 5 & 17.2 & 15 & 17.1 & 20 & 29.6 & 30.7 & 35.4 & 48 & 53 \\
\hline Decile 6 & 15 & 12 & 16.5 & 18.5 & 26 & 27.8 & 31 & 40.7 & 47.4 \\
\hline Decile 7 & 14 & 10.7 & 15 & 16 & 22.3 & 23.6 & 25.6 & 34 & 35 \\
\hline Decile 8 & 11.1 & 10 & 14 & 13.3 & 18 & 21 & 22.2 & 27.8 & 29.6 \\
\hline Decile 9 & 9.8 & 8.6 & 10.1 & 9.3 & 15 & 16.1 & 17.5 & 21 & 24 \\
\hline Decile 10 & 5.5 & 5 & 6 & 5 & 7.5 & 9.5 & 9.2 & 9.2 & 13 \\
\hline
\end{tabular}

Source: Author's calculations based on Plan for Costs and Income of Urban Households of Isfahan (2003-2011)

In sum, investigation of housing accessibility index in Isfahan city shows a substantial difference among different income groups of this city in affording housing. In addition to the fact that, compared to other income groups, the low income groups of the city have to spend a longer period in order to obtain housing, the housing accessibility index have even worsened in low-income groups over time. For instance, whereas in 2003 the households of the first Decile could afford housing by working 49 years, this number rose up to 103 years in 2011, which means this group can never afford housing under current circumstances. Besides, investigation of the conditions of the beginning and end of the period shows that the waiting period for obtaining housing has almost tripled for all Deciles, although there have been fluctuations in the increase and decrease of the waiting period.

\section{Conclusion}

Generally, the trend of formation of economic and spatial duality and diversity in cities and regions commenced and was gradually consolidated after the industrial revolution in Europe and then the emergence of modernity in the periphery countries. In Iran, this trend commenced in the early $20^{\text {th }}$ century, and, as a consequence, increased urbanization resulting from this growth led to the accumulation of various problems such as poverty, homelessness and poor housing in Iran's cities. Faced with horizontal development restrictions, Isfahan city, as one of the province capitals, concentrated a great population of low-income groups in itself. Geographical distribution of low-income groups in Isfahan city is such that most of them reside in dilapidated areas. These areas include old areas containing or non-containing monuments, as well as neighborhoods with informal settlements.

The findings demonstrate that in 2011, the cost of constructing one square meter of lands in Isfahan city is 430,000 rials, whereas in the end of the study period this amount rose to 3,102,000 rials. The greatest increase in housing costs occurred in 2008 (\%20.4), and the lowest in 2010 (\%8.6). Mean housing costs for households of the upper Deciles were higher than those of households of the lower Deciles, such that the greatest increased belonged to the $10^{\text {th }}$ Decile (\%36.1) and the lowest increase belonged to the 4the Decile (\%25.7). Generally, by 2005 , the Gini coefficient of housing costs for urban households followed an increasing trend, and the gap has been widening as of 2006. Investigation of effective demand among income Deciles of the city demonstrated a wide gap between the ability to obtain housing among upper and lower income groups of Isfahan city. With respect to effective demand ability among low-income groups, it can be argued that while in 2003 Deciles 1 to 4 owned 4 to 11 square meters of land, these numbers decreased to 1.9 to 5 square meters in 2011. Based on housing accesibility index, the results demonstrated that the low income Decile couled afford one square meter of housing by saving the income of 75 days; however, at the end of the study period (2011), this number rose up to 206 days. Moreover, in 2001 while the households of the highest-income Decile of Isfahan urban society needed to save the income of 10 days to afford one square meter, this number reached up to 23 days. The important point is the gap between high-income and low-income Deciles in the expected days (saving) for obtaining one square meter which was 10.5 times between the $1^{\text {st }}$ Decile and the $10^{\text {th }}$ one. Furthermore, while in 2003 the households of the $1^{\text {st }}$ Decile could afford their required housing by working 46 years, this number rose up to 103 years in 2011, which meant that it was practically impossible for these households to afford housing.

\section{References}

Anzorena, J. (1993). Supporting shelter improvements for low-income groups .

Arrossi, S, Bombarolo, F, Hardoy, J. E., Mitlin, D., Pérez, C. L., \& Satterthwaite, World Bank. (1993). The Housing Indicators Program: Preliminary Results, Washington, DC: World Bank and UNCHS .

Athari, K. (2003). Plan Evading and deficiencies of low-income housing planning, Collection of research paperes of housing economics, National Land and Housing Organization, Ministry of Housing and Urban 
development, Tehran.

Benton- Short, L., \& Short, J. R. (2008). Cities and Nature, Routledge, Newyork .

Bratt, R. G. (2000). Housing and family well-being. Housing Studies, 17(1), 12-26 .

Brunn, S., Williams, J., \& Ziegler, D. (2003). Cities of the World, World Regional Urban Development, Newyork: Rowman and Littlefield.

Chadwick, G. (1987). Models of Urban Regional System in Developing Countries, Pergamon press .

Chafe, Z. (2007). Reducing Natural Disaster Risks, In State of the World: Our Urban Future, Newyork: Norton Comparisons, Urban Studies, 27(6).

Datta, K., \& Jones, G, A. (2001). Housing and Finance in Developing countries, Routledge,Newyork .

Ellen, I. G., \& Margery, A. T. (1997). Does Neighborhood Matter? Assesing Recent Evidence. Housing Policy Debate, 8(4).

Hardoy, J., Mitlin, D., \& Satterhwait, D. (2001). Environmental Problems in an Urbanizing World, London and Sterling. Environment and Urbanization, 5(1).

Inanlou, A. (2001). Housing planning: an Analysis of Housing Supply and Demand in the North of Qazvin City, MA thesis, Tarbiat Modares University.

Kreiger, J., \& Higgens, D. L. (2002). Housing and health: Time again for public action. American Journal of Public Health, 92(5), 758-768.

Mills, G., Daniel, G., Larry, O., \& David, L. (2006). Effects of Housing Vouchers on Welfare Families. Washington, DC: U.S. Department of Housing and Urban Development .

Rapoport, A. (1969). Housing for and culture, Prentice-Hall.

Rothstein, R. (2000). Inner city nomads: A track to low grades. New York Times (Jan. 9.)

Sadeghi, A. (2003). Feasibility of Local Housing Planning in Qazvin City,' MA thesis, University of Tehran .

Seifoldini, F. (1994). Minimal Housing, Proceedings of the conference on housing development policies in Iran, 1 , Tehran.

Sendich, E. (2006). Planning and urban Standards, Newjersy .

Shafa'at, M. (2006). Investigating policies for obtaining housing of the needy in Iran, MA thesis of Policiy-Making and Iranian Studients, Faculty of Law and Political Science, University of Tehran.

Short, R. (2006). Urban Theory A Critical Assessment,Routledge.

Statistical Center of Iran. (2011). Plan for household cost and income of Isfahan city .

Tofiq, F. (2003). Housing Planning,' Collection of Educational Papers of Housing Planning, Land and Housing Organization, Tehran.

Williams, K. (2000). Achieving Sustainable urban form, E \& FN spon, Londen, U.K.

Yagi, K. (1979) .A Japanese Touch For your home, codansha international.

Zebardast, E. (2003). Regional and Housing Planning, National Land and Housing Organization, Tehran.

Ziari, K., \& Dehghan, M. (2003). Investigating Housing Conditions and Its Planning in Yazd City,' Soffeh, No. 36.

\section{Copyrights}

Copyright for this article is retained by the author(s), with first publication rights granted to the journal.

This is an open-access article distributed under the terms and conditions of the Creative Commons Attribution license (http://creativecommons.org/licenses/by/4.0/). 